\title{
Usefulness of Tissue Doppler Imaging-Derived Atrial Conduction Time for Prediction of Atrial Fibrillation
}

\author{
Toshinori Yuasa, MD, PhD; Yutaka Imoto, MD, PhD
}

$\mathbf{V}$

ulnerability to atrial fibrillation (AF) associates the atrial condition with the critical number of wavelets and multiple reentrant circuits resulting in delayed intra-atrial conduction. ${ }^{1,2}$ Total atrial conduction time (TACT), representing the total time required for atrial electrical activation, can be evaluated as the maximal $\mathrm{P}$-wave duration using single-averaged electrocardiogram (SA-ECG), and is reported to be a powerful predictor of AF. ${ }^{3,4}$ However, this method of measuring TACT is difficult to use in clinical practice because of its time-consuming technique and requirement for special hardware. Merckx et al described an alternative echocardiographic measurement using tissue Doppler imaging (TDI) to estimate TACT. They measured the time from the initiation of atrial depolarization represented by the onset of the P-wave on the 12-lead surface ECG (lead II) until the last atrial depolarization represented by the peak of TDI A' wave at the left atrial (LA) lateral wall (Figure). They also demonstrated that this TDI-derived atrial conduction time (PA-TDI duration) using echocardiography equipment ${ }^{5}$ had the best correlation with TACT measured by SA-ECG. Furthermore, PA-TDI duration also enables practical and better prediction of new-onset $\mathrm{AF},{ }^{6}$ recurrence after $\mathrm{AF}$ ablation ${ }^{7}$ and $\mathrm{AF}$ after acute myocardial infarction ${ }^{8}$ compared with LA volume or other parameters.

\section{Article p 101}

Postoperative AF is one of the most common complications after cardiac surgery, ${ }^{9}$ and $94 \%$ of cases are prone to occur up till postoperative day $6 .{ }^{10}$ Recently, the prediction of AF after off-pump coronary artery bypass grafting (CABG), ${ }^{11}$ and aortic valve replacement (AVR) for aortic valve stenosis (AS) using PA-TDI duration was reported. ${ }^{12}$

In this issue of the Journal, Takahashi et $\mathrm{al}^{13}$ investigate the prediction of postoperative AF after mitral valve surgery (MVS) for mitral valve regurgitation (MR) using TDI-derived atrial conduction time. MR is one of the representative valvular heart diseases associated with a large LA. Therefore, newonset AF after MVS and disappearance of the MR jet may facilitate the formation of LA thrombosis and increase the risk of stroke compared with other cardiac surgery. The important findings from their study are as follows.

Firstly, the overall incidence of postoperative AF was $60 \%$ (44 of 73 patients) and a relatively high incidence. The criteria of postoperative AF in this study was AF lasting $>5 \mathrm{~min}$. All

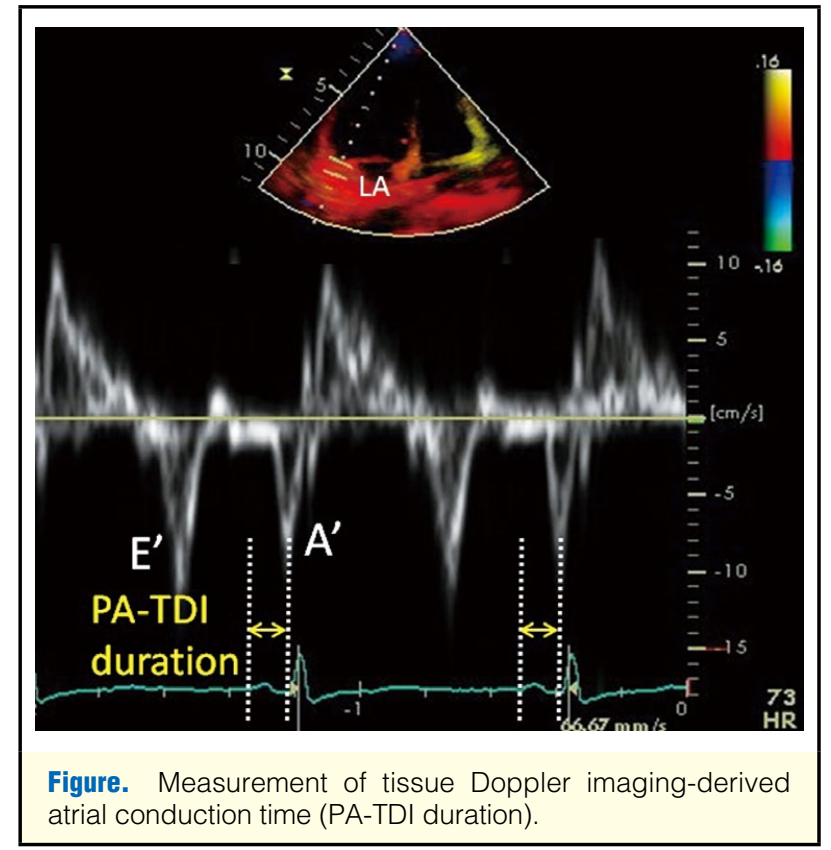

patients were monitored with continuous ECG telemetry for $\geq 2$ weeks following MVS. The current study was able to detect new-onset of AF without fail compared with previous reports. ${ }^{6-8}$ Secondly, under univariate analysis of prediction for postoperative $\mathrm{AF}$, a degenerative $\mathrm{MR}$, the duration of $\mathrm{MR}$, A-wave peak velocity, PA-TDI duration and preoperative CVP were significant predictors of postoperative AF. Multivariate analysis demonstrated that degenerative MR (95\% confidence interval $(\mathrm{CI})$ : $1.41-15, \mathrm{P}=0.0112)$ and $\mathrm{PA}-\mathrm{TDI}$ duration $(95 \%$ CI: $1.01-1.07, \mathrm{P}=0.0048)$ were significant and independent predictors of postoperative AF. The reason for the poor association of LA volume parameters and postoperative AF in this study was the larger LA volume in both the AF and non-AF groups (LA volume index, AF $58.7 \pm 20.6 \mathrm{ml} / \mathrm{m}^{2}$ vs. Non-AF $\left.53.4 \pm 16.2 \mathrm{ml} / \mathrm{m}^{2} \mathrm{P}=0.27\right)$.

The current results were a little different from previous reports analyzing patients after off-pump $\mathrm{CABG}^{11}$ or AVR. ${ }^{12}$ Multivariate analysis demonstrated that postoperative AF after

The opinions expressed in this article are not necessarily those of the editors or of the Japanese Circulation Society.

Received November 24, 2015; accepted November 24, 2015; released online December 9, 2015

Department of Cardiovascular Medicine and Hypertension (T.Y.), Department of Cardiovascular and Gastroenterological Surgery (Y.I.), Graduate School of Medical and Dental Sciences, Kagoshima University, Kagoshima, Japan

Mailing address: Toshinori Yuasa, MD, PhD, Department of Cardiovascular Medicine and Hypertension, Graduate School of Medical and

Dental Sciences, Kagoshima University, 8-35-1 Sakuragaoka, Kagoshima 890-8520, Japan. E-mail: yuasan@ hotmail.com

ISSN-1346-9843 doi:10.1253/circj.CJ-15-1256

All rights are reserved to the Japanese Circulation Society. For permissions, please e-mail: cj@j-circ.or.jp 
Table. Prediction of AF Using Tissue Doppler Imaging-Derived Atrial Conduction Time (PA-TDI)

\begin{tabular}{|c|c|c|c|c|c|}
\hline & & No. of patients & & I duration & \\
\hline & & $\begin{array}{l}\text { Postoperative } \\
\text { (new-onset) }\end{array}$ & AF & Non-AF & Cut-off (AUC) \\
\hline & & AF (\%)/ non-AF & & & \\
\hline de Vos et $a^{6}$ (2009) & $\begin{array}{l}\text { New-onset AF } \\
680 \pm 290 \text { days follow-up }\end{array}$ & $15(6) / 234$ & $172 \pm 25$ & $150 \pm 20^{*}$ & $165(0.74)$ \\
\hline Antoni et $a l^{8}(2010)$ & $\begin{array}{l}\text { New-onset AF after AMI } \\
21 \pm 13 \text { months follow-up }\end{array}$ & $38(6) / 575$ & $138 \pm 29$ & $109 \pm 16^{\dagger}$ & $127(0.84)$ \\
\hline den Uijl et al ${ }^{7}$ (2011) & $\begin{array}{l}\text { Recurrence after AF ablation } \\
13 \pm 3 \text { months follow-up }\end{array}$ & $74(35) / 139$ & $146 \pm 20$ & $124 \pm 23^{\dagger}$ & $-(0.765)$ \\
\hline Fujiwara et al11 (2014) & $\begin{array}{l}\text { AF after cardiac surgery } \\
\text { (Off-pump CABG) } 1 \text { week follow-up }\end{array}$ & $35(40) / 53$ & $156 \pm 20$ & $128 \pm 15^{\ddagger}$ & $141(0.85)$ \\
\hline Takahashi et al ${ }^{12}$ (2014) & $\begin{array}{l}\text { AF after cardiac surgery } \\
\text { (AVR for AS), } \geq 1 \text { week follow-up }\end{array}$ & $41(65) / 22$ & $155 \pm 19$ & $137 \pm 13^{\S}$ & $147.3(0.804)$ \\
\hline Takahashi et al ${ }^{13}$ (2015) & $\begin{array}{l}\text { AF after cardiac surgery } \\
\text { (MVS for MR), } \geq 2 \text { weeks follow-up }\end{array}$ & $44(60) / 29$ & $159 \pm 22$ & $141 \pm 20^{\dagger}$ & $159.4(0.737)$ \\
\hline
\end{tabular}

${ }^{*} \mathrm{P}=0.001,{ }^{\mathrm{t}} \mathrm{P}<0.001,{ }^{\mathrm{f} P}=0.0001, \mathrm{\$} \mathrm{P}<0.01 \mathrm{vs}$. new-onset $\mathrm{AF}$. AF, atrial fibrillation; AMI, acute myocardial infarction; AS, aortic stenosis; AUC, area under curve; AVR, aortic valve replacement; $\mathrm{CABG}$, coronary artery bypass grafting; MR, mitral valve regurgitation; MVS, mitral valve surgery.

off-pump CABG was significantly associated with the LA volume index (95\% CI: 1.02-1.20, $\mathrm{P}=0.01)$ and PA-TDI duration (95\% CI: $1.06-1.16, \mathrm{P}=0.0001)$. On the other hand, postoperative AF after AVR for AS had a significant association with age (95\% CI: 1.03-1.28, $\mathrm{P}=0.016)$ and $\mathrm{PA}-\mathrm{TDI}$ duration (95\% CI: $1.02-1.13, \mathrm{P}=0.0072$ ).

PA-TDI duration has been proven to be a predictor of postoperative or new-onset AF in various situations (Table). Previous and current studies each show their cut-off value of PA-TDI duration for predicting AF. The current study would also contribute to the clinical utility of PA-TDI duration as a predictor for postoperative AF in patients after MVS for MR.

\section{References}

1. Merckx KL, De Vos CB, Palmans A, Habets J, Cheriex EC, Crijns $\mathrm{HJ}$, et al. Atrial activation time determined by transthoracic Doppler tissue imaging can be used as an estimate of the total duration of atrial electrical activation. J Am Soc Echocardiogr 2005; 18: $940-$ 944.

2. Moe G. On multiple wavelet hypothesis of atrial fibrillation. Arch Int Pharmacodyn Ther 1962; 140: 183-188.

3. Guidera SA, Steinberg JS. The signal-averaged $\mathrm{P}$ wave duration: A rapid and noninvasive marker of risk of atrial fibrillation. J Am Coll Cardiol 1993; 21: 1645-1651.

4. Fuenmayor AJ, Ramirez L, Fuenmayor AM. Validation of interatrial conduction time measurement by means of echo-Doppler. Arch Cardiol Mex 2002; 72: 125-128.

5. Nakatani S, Akaishi M, Asanuma T, Hashimoto S, Izumi C, Iwanaga S, et al. Guidelines from the Japanese Society of Echocardiography: Guidance for the management and maintenance of echocardiography equipment. J Echocardiogr 2015; 13: 1-5.
6. de Vos CB, Weijs B, Crijns HJ, Cheriex EC, Palmans A, Habets J, et al. Atrial tissue Doppler imaging for prediction of new-onset atrial fibrillation. Heart 2009; 95: 835-840.

7. den Uijl DW, Gawrysiak M, Tops LF, Trines SA, Zeppenfeld K, Schalij MJ, et al. Prognostic value of total atrial conduction time estimated with tissue Doppler imaging to predict the recurrence of atrial fibrillation after radiofrequency catheter ablation. Europace 2011; 13: $1533-1540$.

8. Antoni ML, Bertini M, Atary JZ, Delgado V, ten Brinke EA, Boersma E, et al. Predictive value of total atrial conduction time estimated with tissue Doppler imaging for the development of newonset atrial fibrillation after acute myocardial infarction. Am J Cardiol 2010; 106: 198-203.

9. Echahi N, Pibarot P, O'Hara G, Mathieu P. Mechanisms, prevention, and treatment of atrial fibrillation after cardiac surgery. J Am Coll Cardiol 2008; 51: 793-801.

10. Aranki SF, Shaw DP, Adams DH, Rizzo RJ, Couper GS, VanderVliet $\mathrm{M}$, et al. Predictors of atrial fibrillation after coronary artery surgery: Current trends and impact on hospital resources. Circulation 1996; 94: 390-397.

11. Fujiwara M, Nakano Y, Hidaka T, Oda N, Uchimura Y, Sairaku A, et al. Prediction of atrial fibrillation after off-pump coronary artery bypass grafting using preoperative total atrial conduction time determined on tissue Doppler imaging. Circ J 2014; 78: 345-352.

12. Takahashi S, Fujiwara M, Watadani K, Taguchi T, Katayama K, Takasaki T, et al. Preoperative tissue Doppler imaging-derived atrial conduction time can predict postoperative atrial fibrillation in patients undergoing aortic valve replacement for aortic valve stenosis. Circ J 2014; 78: $2173-2181$.

13. Takahashi S, Katayama K, Watanabe M, Kodama H, Taguchi T, Kurosaki T, et al. Preoperative tissue Doppler imaging-derived atrial conduction time predicts postoperative atrial fibrillation in patients undergoing mitral valve surgery for mitral valve regurgitation. Circ J 2016; 80: 101-109. 